\title{
Contesting Authoritarianism
}

\author{
Jeffrey C. Isaac
}

$\Lambda$ s I write this Introduction, in the first week of March, Ukraine is in the midst of a crisis with portentous regional and global implications. A government that is barely two weeks old occupies the seat of power in Kiev, the nation's capital, where months of massive "Euromaidan" demonstrations against the elected government of President Viktor Yanukovich, fueled by massive repression and the escalation of street violence, forced the President from office. The President, who fled the capital in secrecy, has resurfaced in the eastern city of Kharkiv, where he has denounced the new government, declared his own continued authority as the elected leader of Ukraine, and called upon his Russian allies to offer him protection and to help "restore law and order." Russian troops now occupy the Crimean peninsula on the orders of President Vladimir Putin, who has declared, with the support of the Russian Parliament, that he has the right to "defend Russian nationals" and Russia's national interests in Ukraine. The situation involves elements of civil war and elements of outright foreign invasion. There is the red of blood in the streets, and little "Orange."

The deposed leader was elected; but the regime that he led was widely considered a "hybrid," a form of "electoral authoritarianism," in which the opposition was severely constrained (and some of its leaders jailed) and power exercised in highly coercive and predatory ways. The "Euromaidan" movement, which progressively grew in size and strength amid cycles of protest and repression, was diverse, including both liberals and right-wing nationalists. It was largely non-violent, though at times some of its participants resorted to violence, whether defensive or provocative. It was linked in complex ways to a range of oppositional political parties who hoped to draw support, and eventually to electorally unseat the government. Some of the party leaders were liberal democrats, and some were not. Many were linked to "oligarchs" increasingly unsatisfied with the President's predatory methods.

Has Ukraine experienced or is it experiencing a revolution? Does the new government in Kiev represent a change of regime, or only a change of government intended to secure the old regime? What dynamics of social protest, political opposition, elite maneuvering, transnational activism, and geopolitical intrigue have brought about the current situation? Does the situation represent a crisis of authoritarianism or a crisis of post-"Orange Revolution" democratization?

Much of the material in this issue of Perspectives speaks directly to these pressing contemporary questions. These themes have long been at the heart of modern political science. As I was reflecting on them for this issue, I was drawn repeatedly to an old classic, Robert Dahl's Polyarchy: Participation and Opposition. The bookwhich has experienced 25 printings since it was first published in 1971, and has been translated into at least ten languages - is a foundational text for the comparative study of democratization and authoritarianism. The book begins with a simple question, starkly posed: "Given a regime in which the opponents of the government cannot openly and legally organize into political parties in order to oppose the government in free and fair elections, what conditions favor or impede a transformation into a regime in which they can?" In what follows, Dahl outlines a range of regime types considered along two dimensions - the level of inclusion and the level of opposition. The book's central theme is the role of public opposition in contesting authority, fracturing hegemonic systems, and possibly sustaining "polyarchal" alternatives.

This issue of Perspectives features this very theme.

Barbara Geddes, Joseph Wright, and Erica Frantz's "Autocratic Breakdown and Regime Transitions: A New Data Set," proceeds from a straightforward observation: that while there are "three possible outcomes when a dictator is ousted: regime survival under new leadership, democratization, and replacement by a new autocratic regime," systematic investigation of the range of outcomes is rare. In order to facilitate more systematic and theoretically informed inquiry, the authors outline their own Autocratic Regimes Data Set; provide examples of how the data can be used to answer important policy-relevant questions; and compare their dataset to two proxies for autocratic breakdown often used in empirical research. As they explain: "The data identify transitions, whether to democracy or a new autocracy, when basic rules about the identity of the leadership group change. 
Regime breakdown and characteristics of the government that follows breakdown are coded independently of each other, making it possible to more precisely investigate why some autocratic regime breakdowns lead to democratization while others do not." As the authors make clear, the new dataset has important implications for the comparative analysis of democratization and authoritarian resilience: "Despite optimism regarding the demise of autocracy as a form of government after the Cold War, about a third of the world's countries and many of its people are still ruled by autocratic governments. To better understand what might undermine contemporary autocracies and whether their collapse is likely to lead to democracy, the reimposition of autocratic rule, or future instability and violence, we need better data that more carefully measure autocratic regime and transition characteristics. Our new data set provides it."

Guillermo Trejo's "The Ballot and the Street: An Electoral Theory of Social Protest in Autocracies" also analyzes the dynamics of contestation under authoritarian regimes. Trejo's framework draws from Doug McAdam and Sidney Tarrow's "Ballots and Barricades: On the Relationship between Elections and Social Movements," an essay published in the June 2010 issue of Perspectives (see also Tarrow's Critical Dialogue with W. Lance Bennett in this issue). Though he focuses on Latin America, the questions he poses are clearly of much broader provenance, as current events in Ukraine make clear: "Why does the introduction of multiparty elections in autocracies stimulate the rise of major cycles of protest? Why does the activation of the ballot politicize the street and why does the introduction of multiparty elections give rise to socio-electoral coalitions between opposition parties and social movements? When do authoritarian elections become an important mechanism for the aggregation of local and isolated protest events into major waves of political mobilization?" Trejo argues that under semi-authoritarian conditions "opposition parties have powerful incentives to recruit social movements to help them build a core electoral constituency and lead popular mobilization," and that social movement leaders similarly have incentives to ally with opposition parties "when opposition party leaders become major sponsors of their causes and provide them with important financial and logistic resources and institutional protection to continue mobilizing during non-election times." At the same time, Trejo points out that there are also tensions between parties and movements, related to both goals and styles of action (this theme is also developed in Michaelle Browers's review essay on "Islamism and Authoritarianism," and it is touched upon in our symposium on Wael Hallaq's The Impossible State: Islam, Politics, and Modernity's Moral Predicament). As Trejo writes: "Understanding the logic of the street in autocracies is important because social protest is one of the few mechanisms of policy negotiation for independent citizens and groups. But understanding the process of aggregation of isolated movements and protest events into major cycles of mobilization is theoretically and politically crucial because these waves of protest can be precursors of the democratization of authoritarian regimes or of the outbreak of armed insurgencies and civil war."

If Trejo analyzes the dynamics of opposition that can produce political openings, Dan Slater, Benjamin Smith, and Gautam Nair's "Economic Origins of Democratic Breakdown? The Redistributive Model and the Postcolonial State" centers on the circumstances under which political elites may seek to restrict political space and institute more authoritarian rule. Their target is a view, articulated by Daron Acemoğlu and James Robinson in their Economic Origins of Dictatorship and Democracy, that: "the main threat against democracy comes from its redistributive nature." Drawing on a combination of statistical and case study methods, Slater and Smith forward a "state-centered alternative," according to which "the roots of democratic fragility in the contemporary world primarily grow out of the political soil of weak states - not the economic soil of class conflict." As they make clear, the question at issue has enormous theoretical and practical importance: "At the heart of the scholarly debate presented in this article is an enormous practical and normative question: are democracies best secured by limiting state power, or by expanding it? The logical upshot of redistributive models is that democracies risk collapse unless the state refrains from making redistributive claims upon the rich. Our own analysis suggests that democracies do not imperil themselves through downward redistribution, but through failing to invest in the state-building efforts necessary to fulfill a wide range of governance tasks."

While Slater and Smith focus on the dynamics of democratic breakdown in postcolonial states, Harris Mylonas focuses on the danger of democratic breakdown in the heart of Europe. His review essay, "Democratic Politics in Times of Austerity: The Limits of Forced Reform in Greece," offers a broad interpretation of the current Greek economic and political crisis and its implications for thinking about the Eurozone and for democratic stability. As Mylonas writes: "The Greek case merits further specialized study since it most clearly illustrates the challenges of democratic politics in times of austerity and may serve as a window to the future of other European polities. In Greece, new discourses on the role of populism, nationalism, and violence in politics have re-emerged in disturbingly polarized ways. But the rise of right-wing extremism and the consequent challenges to multiculturalism coupled with the ambivalence concerning the future of the European project are not just Greek problems. They can be found in many corners of Europe, and thus ought to be of concern to all who care about the future of Europe ... . Greece confronts these challenges in a particularly 
serious form. But it is hardly alone, as similar narratives unfold throughout Europe, from Ireland to Spain and Italy to Romania, Hungary, and Bulgaria."

Daniel M. Brinks and Varun Gauri's "The Law's Majestic Equality? The Distributive Impact of Litigating Social and Economic Rights" addresses an important form of distributive politics that has recently emerged in a range of settings, including India, Indonesia, South Africa, Brazil and Colombia: "changes in global constitutionalism that seem explicitly designed to benefit the disadvantaged. These changes have led to an explosion of litigation and the judicialization of the politics of social provision that appear, on their face, to seek to expand the supply of goods that are important to the poor, such as health care, education, and social provision more generally." Brinks and Guari argue that scholars "need to pay closer attention to the broad, collective effects of legal mobilization, rather than focusing narrowly on the litigants and the direct benefits they receive." They then indicate the value of such a broader perspective, showing "that litigation pursued in legal contexts that create the expectation of collective effects is more likely to avoid the potential anti-poor bias of courts. On the other hand, policy areas dominated by individual litigation and individualized effects are more likely to experience regressive outcomes."

Brinks and Guari's article originated in a Policy Research Working Paper supported by the World Bank's Development Research Group. Blending theoretical and policy concerns, the piece seeks "to lay bare some of the assumptions on which most distributive critiques of SE rights litigation are based, suggest when they might or might not hold, and outline the beginnings of a research agenda on the progressive potential of litigation and enforceable social and economic rights." Regarding their call for a broader focus on legal mobilization, Brinks and Guari remark that: "As always, but especially here, the choice of research design is highly likely to determine the findings." This theme, sounded also in the piece by Geddes et al., is echoed in a number of other essays published in this issue that in different ways enjoin political scientists to broaden their horizons.

Debra Javeline's "The Most Important Topic Political Scientists are Not Studying: Adapting to Climate Change" argues that while many political scientists have turned their attention to environmental politics, few "currently study climate change adaptation or are even aware that there is a large and growing interdisciplinary field of study devoted not just to mitigating greenhouse gas emissions but to reducing our vulnerability to the now inevitable impacts of climate change ... This new critical field ... is currently populated by climate scientists, ecologists, NGOs, environmental lawyers, urban planners, engineers, computer scientists, development experts, resource managers, and policymakers. Political scientists have been largely absent from the conversation, despite the importance of the topic and the need for their contributions. Many of the most pressing questions about adaptation are less about science and more about political, social, and economic behavior and the institutions that facilitate or obstruct that behavior - questions that political scientists are uniquely trained to answer." Javeline thus calls "for political scientists from all subfields to contribute to climate change adaptation research and advance the adaptation conversation in mainstream political science."

In "Explaining the Unexpected: Comparing 1989 and the Arab Spring," Marc Morjé Howard and Meir R. Walters provocatively argue that scholars of Eastern Europe and the Middle East and North Africa were ill-equipped to anticipate and then to explain popular mobilizations and political upheavals, and that the reason was that "dominant paradigms within the discipline caused scholars of both regions to overemphasize the determinants of broadly construed regime change, and to marginalize alternate research agendas that may be more relevant to understanding these political transformations." They thus maintain that "Scholars should focus more directly on how political repression and participation are debated and enacted locally, and how oppressive power relations can be established, routinized, and contested across different regime types. This would enable renewed focus on the study of political changes, such as nascent social movements, that may or may not be tied to democratization." In the symposium that follows, Eva Bellin, Ellen Lust, and Marc Lynch—scholars who have done important work on MENA authoritarianism and the Arab Spring-offer critical rejoinders, each of which maintains that Howard and Walters caricature the field of Middle East studies within political science. The exchange highlights the importance of historical and regional comparisons, the possibilities and the limits of prediction in political science, and the role of the genuinely unanticipated in political life.

Sanford F. Schram focuses on a different, though related, surprise: the Occupy movement that swept across the United States and Canada in 2011. Like the pieces by Javeline and by Howard and Walters, Schram's "The Great Disconnect: Occupy and Political Science" offers a reflective, critical account of the promise and limits of academic political science. As Schram characterizes the Occupy movement, "[It] ought to be understood, and appreciated, for what it is: a distinctive form of movement politics that articulates the preoccupations and political styles of today's young people, but also the broader economic concerns of all-young and old, single or with children, black and white, formerly middle class or persistently poor-who are rendered vulnerable by the economic transformations in the wake of the Great Recession. Occupy ought to be seen as an expression of and a protest against the pervasiveness of what Judith Butler and others 
have termed 'precarity."' At the same time, Schram insists that Occupy "not only furnishes Political Science with explanatory challenges and opportunities. It also poses questions about the very character of political science inquiry... Too much of political science research remains informed by the belief that the goal of that research is help develop theoretical explanations of political phenomena irrespective of whether that research helps people address the political challenges they currently confront ... Learning from activists what politics is, what it means to them, what their political concerns are, and how those concerns can be best expressed at any one point in time, is actually an important form of political science research historically, and it would be a mistake to forget that now in the rush to criticize the youthful exuberance of Occupy, because or in spite of the fact that it has yet to realize all its supporters had hoped. So, perhaps, then, there is a generational issue. Perhaps old political scientists need to be open to learning from the young activists who are their students, and the younger colleagues who are drawn to the activists and sometimes are themselves activists. The Child is indeed at times Father to the man."

Schram invokes a trope with broad resonance at least since the publication of William Wordsworth's 1802 poem "My Heart Leaps Up When I Behold."

Perspectives is not your garden variety academic journal. And so I'd like to close by quoting this poem, and then offering a few words of relevance to our discipline and to this journal:

\footnotetext{
My heart leaps up when I behold

A rainbow in the sky:

So was it when my life began;

So is it now I am a man;

So be it when I shall grow old,

Or let me die!

The Child is father of the Man;

I could wish my days to be

Bound each to each by natural piety.
}

On February 5, 2014, Robert Dahl passed away at the age of 98. Dahl was a titan of modern political science. He was also my teacher, my mentor, and my friend. I have commented elsewhere on the personal meaning of his passing to me. Here, in this academic-scholarly journal, I would like to offer a very brief reflection on the meaning of Bob Dahl for Perspectives on Politics, and for the broader project of disciplinary broadening for which the journal is an important platform.

Bob Dahl was a pioneer of the "behavioral revolution" in political science. An important moment in the recent history of our discipline was the publication of Gabriel Almond's "Separate Tables: Schools and Sects in Political Science" in the Autumn 1988 issue of PS. This piece was important because Almond, like Dahl, was in the vanguard of the behavioral revolution, and yet here he was raising serious questions about what this revolution had wrought, and whether the discipline's obsession with a particular conception of "scientific method" had generated a kind of professional autism. What many readers of this journal may not recall is that many of the themes developed in Almond's 1988 essay were anticipated by an earlier article, published in December 1961 in the American Political Science Review: Bob Dahl's "The Behavioral Approach in Political Science: Epitaph for a Monument to a Successful Protest."

This is a complicated essay and, preceding Almond's by over a quarter-century, it should be no surprise that it is much more muted and ambivalent-and thus also more foreboding - about the possibly baneful if unanticipated consequences of behavioralism's valorization of "scientific method." Dahl extols the "progressive" advantages of behavioralism. He also notes some of its dangers. He writes: "the scientific outlook in political science can easily produce a dangerous and dysfunctional humility ... The danger, of course, is that the quest for empirical data can turn into an absorbing search for mere trivialities unless it is guided by some sense of the difference between an explanation that would not matter much even if it could be shown to be valid by the most advanced methods now available, and one that would matter a great deal if it should turn out to be a little more or a little less plausible than before, even it still remained in considerable doubt . . . it seems clear that unless the study of politics generates and is guided by broad, bold, even if highly vulnerable general theories, it is headed for the ultimate disaster of triviality."

If triviality is one danger, a second is that the behavioral revolution has created disturbing and dysfunctional divisions within the discipline. He thus writes about five "fragments in search of a unity," holding out the hope that these fragments-empirical research, normative theory, history, general theory, and "speculation" and "imagination"-can somehow be brought into a productive and integrative balance.

Dahl's reflections were prescient.

The essay's tone of intellectual openness, and selfcriticism, was a hallmark of Dahl's writing. Perhaps the most significant example of this openness was his short 1970 book, After the Revolution?, in which he sought to bring his own approach to democratic theory into dialogue with student radicals - many of them future political scientists-who were strong critics of "establishment" politics and "establishment" political science. But this disposition was indeed anticipated in his 1961 APSR essay where, after outlining the aspirations of behavioralism, he notes that his discussion: "leaves unanswered whatever questions may be raised as to the present or potential achievements of this mood of protest, skepticism, reform, and optimism. Fortunately, there is an element of selfcorrection in intellectual life. The attempt to increase the scientific competence of political studies will inevitably be 
judged by the results. And the judges of the next generation will share the skepticism of the past."

The next generation.

The Child is Father to the Man: and so I have the privilege, and the honor, of reflecting in these pages, of the journal that I now edit, on the extraordinary intellectual legacy of my teacher, Bob Dahl.

At the same time, it is not that much of a stretch to suggest that this very journal is in an important sense the intellectual "grandchild" of Bob Dahl.

Think about it. Instrumental to the journal's very creation was the work of APSA President Robert
Putnam, who was a student of Bob Dahl's at Yale. Putnam's 2002 APSA Presidential Address, "The Public Role of Political Science," appeared in this journal's second issue, and set the tone for the journal's agenda.

This journal's founding editor, whose vision and organizational and editorial abilities set the journal on a strong and clear path, was Jennifer Hochschild, who was a student of Bob Dahl's at Yale.

I am honored to continue this legacy.

As Wordsworth writes: "I could wish my days to be Bound each to each by natural piety." 


\title{
The Centrality of Books to Political Science and to Perspectives on Politics
}

\author{
By Jeffrey C. Isaac, Editor in Chief
}

Almost half of every issue of Perspectives is dedicated to our Review section. This structure of the journal is something that we inherited, for when Perspectives was created, it was decided to move the APSA book reviews, which had previously been published in the APSR, to Perspectives, and to open up the new journal to a range of writing formats.

We inherited this structure, but we also embraced it.

Indeed, I assumed the position of Editor in Chief of the entire journal after having served for four years as the Book Review Editor under the editorship of my predecessor, Jim Johnson. During my tenure as Book Review Editor we made a conscious decision to innovate with this section, by creating new formats-Critical Dialogues, Book Symposia, different kinds of thematic review essays, and Review Editor Introductions highlighting common themes - and trying to make the "back end" of Perspectives a space for lively conversation across conventional subfield and methodological divides in the discipline. These innovations were announced and explained in my inaugural editorial statement, "A Statement from the Book Review Editor" (Perspectives on Politics, March 2006, pp. 3 4 ), and the approach to the journal's treatment of books has remained true to the perspective outlined in that public text.

When I was offered the editorship of the entire journal in 2009, I agreed to accept this position on the basis of a clearly defined vision that was grounded in our experience with the Review section, and I was committed to editing the entire journal as a whole. My reason was straightforward: I believed that the journal was a unique and precious intellectual resource, and I was-and am-deeply committed to placing it on the strongest possible footing as a venue that features a wide range of political science perspectives and formats in a genuinely integrated way. It is surely possible for the two "ends" of the journal to be edited by separate individuals, working together in a collaborative fashion. But I was and am strongly committed to the idea that the two ends can and should be integrated into a single whole; that each "end" should in fact have diverse formats, so that in fact the journal would be much more complicated and interesting than a simplistic oppo sition of "articles" and "reviews" implies; and that these formats should speak to one another.

This vision was endorsed by the APSA officials - the search committee chaired by Rogers Smith, APSA President Peter Katzenstein, and the APSA Council-who unanimously supported my appointment.

When my editorial team took over the entire journal in 2009, we "branded" the journal as "A Political Science Public Sphere," and worked hard to nurture synergies between the research articles and essays published in the journal's "front end" and the reviews and book discussions published in its "back end" (this vision was announced in "Perspectives on Politics: A Political Science Public Sphere," my editorial statement published in the March 2010 issue, and now printed at the beginning of each issue). My staff and I have devoted enormous energy to this approach to the journal, with the strong support of our dedicated Editorial Board and with the support of the APSA Council. These efforts were recognized by the 2011 Performance Review Committee that recommended the extension of our editorial tenure. But in my view the most important "recognition" of this approach is the fact that we continue to enjoy the enthusiastic participation of many hundreds of authors and reviewers every year, and to produce a publication that includes a wide range of excellent contributions across a range of formats.

At the heart of the journal as it has come to be structured, read, and appreciated within the profession, is the deliberate effort of our editorial team to discern, nurture, and publicize complementarities, synergies, and broad thematic interests that might otherwise be insufficiently recognized by our increasingly specialized academic life. Our entire range of formats is dedicated to this end. We have nurtured the production of research articles that are rigorous, rigorously peer-reviewed, and at the same time are written and framed more broadly than conventional research articles. We have nurtured a range of conversations about political science books, and promoted conversations between our articles and our book reviews and essays. These connections have been essential to our vision of "a political science public sphere." 
Readers of the journal will be familiar with this range of formats, and with their complementarities:

- Research articles

- "Reflections" essays

- Book Review Essays

- Book Symposia

- Book Critical Dialogues

- "Undisciplined" Reviews and Review Essays (featuring reviews of books from other disciplines)

- A special thematic Book Review section in each issue

- Standard single, double, and triple Book Reviews

Readers will also be familiar with the ways that we have sought to plan our production schedule so we can package writings in these formats together thematically, and highlight these themes in my Editor Introductions. These efforts draw scholarly and public attention to broad and interesting themes. And by promoting broad and relevant scholarly discussion, they also help us reach beyond the discipline, and to gain the attention, and sometimes even the involvement, of journalists, policy intellectuals, and sometimes even a broader reading public. Recent examples include:

- Our June 2012 issue featuring work on violence

- Our September 2012 special $10^{\text {th }}$ Anniversary issue on "Post-Katrina New Orleans and the Politics of Reconstruction"

- Our March 2013 issue featuring work on "The Politics of Inequality in the Face of Financial Crisis"

- Our June 2013 issue featuring work on "Nature and Politics"

It is sometimes overlooked how central our Book Review section is to these efforts. But even a casual perusal of any recent issue of Perspectives will remind colleagues of the centrality of books.

I have been a professional political scientist for over thirty years. We are all well acquainted with the still widely accepted notion that book review assignments are convenient means of getting a free book that you want to read and of dashing off a thousand-word commentary during one's breaks from "real" research and writing. For the past eight years we have worked tirelessly, and successfully, to counter this unfortunate notion.

Books are important, and so serious intellectual attention to them is important.

While promptly published scholarly articles are also important, the book format remains the only format that allows scholars, in every field and from every perspective, to take the time and space to develop an argument in depth. Books are at the heart of political science. Important books help to create new research agendas. The names Almond or Dahl or Katzenstein or Putnam or Skocpol or Ostrom or Riker or Olson or Fenno or Mansbridge or Aldrich do not evoke journal articles. Each evokes an important book, and typically more than one of them. Every year many hundreds of new political science books containing new political science perspectives are published. We know this. The Book Exhibit at the annual APSA conference is one of the main attractions for almost everyone.

These books seek and deserve more than mere citation and more than glorified "Book Note" type reviews. They deserve serious discussion in a serious scholarly context. They deserve well-written reviews that are carefully edited by editors who work with reviewers, and prompt them to think a bit more broadly, and to view their book reviews as real scholarly engagements. Such reviews do much more than publicize and provide short cuts to books that readers might not otherwise know about. They engage the books and make them really a part of serious scholarly dialogue.

But there is something else: these reviews make their authors part of seriously scholarly dialogue.

Most of our colleagues do not work at research-intensive universities. Most of them spend most of their time teaching, often with heavy loads, either as tenured or tenuretrack professors at teaching institutions, or as adjuncts and part-time academic workers. For many of our colleagues, the chance to write a fine book review, and to have it seriously engaged by an editor, and to have it published in a "flagship research journal," is one of the only significant opportunities they may have to write and to publish in a given year.

Every year Perspectives on Politics publishes hundreds of book reviews written by a very wide range of scholars with a wide range of institutional affiliations. We are very serious about the range and diversity of the contributors to our book review section. One reason is because it allows our journal to reach broadly, and to include many of readers as contributors. This "community-building" function of Perspectives is very important, for a scholarly community ought to be linked by scholarly conversation in which each participant has genuine opportunities to speak as well as to listen and to be an author as well as a reader.

But this kind of inclusion is also important in an epistemic sense. For it "enforces" a breadth of scholarly perspective, and brings expert discourses into conversation with more generalist perspectives, to the benefit of the kind of true critical engagement that is the heart of the scientific enterprise. In this sense, every 1500 word book review that we publish is much more than a professional "service"; it is a serious contribution to scholarship and to the development of scholarly research. And the publication of these reviews in a flagship journal of political science, alongside rigorously peer reviewed research articles, essays, symposia, and dialogues, highlights their importance.

We are excited about the range of formats contained within Perspectives, and the way that they work together to project a vision of scholarly and intellectual seriousness. We believe that in this age of specialization, "modularity," 
and almost costless digital creation and circulation of texts, it is important for an intellectually serious political science discipline to have at least one broad, integrated, and intellectually serious journal that features a range of perspectives, formats, and scholars.

We believe, in short, that it is important for there to be a political science public sphere.
We are also grateful to the many colleagues who support us in these efforts, and who embrace the chance to be active participants in and contributors to the journal and its many formats. We continue to receive a growing number of article submissions, and we have many exciting book review special features planned in the coming issues. As we move forward, we welcome your ideas and suggestions. 